\title{
Insulin Effect on Fetal Glucose Utilization
}

\author{
MICHAEL A. SIMMONS, ${ }^{(22)}$ M. DOUGLAS JONES, JR., FREDERICK C. BATTAGLIA, AND \\ GIACOMO MESCHIA \\ Division of Perinatal Medicine, University of Colorado Medical Center, Denver, Colorado, USA
}

\begin{abstract}
Summary
Insulin infused into a sheep fetus over a 3 -hr period at the rate of $\sim 0.24 \mathrm{U} \cdot \mathrm{kg}^{-1} \cdot \mathrm{h}^{-1}$ increased fetal glucose uptake (utilization) from $4.4 \pm 0.7 \mathrm{mg} \cdot \mathrm{min}^{-1} \cdot \mathrm{kg}^{-1}$ to $6.9 \pm 0.9$ $\mathrm{mg} \cdot \mathrm{min}^{-1} \cdot \mathrm{kg}^{-1}$ as compared to a noninsulin control period. Insulin administration did not alter fetal oxygen consumption $\left(8.6 \pm 0.7 \mathrm{ml} \cdot \mathrm{min}^{-1} \cdot \mathrm{kg}^{-1}\right.$ vs. $\left.7.7 \pm 0.7 \mathrm{ml} \cdot \mathrm{min}^{-1} \cdot \mathrm{kg}^{-1}\right)$, umbilical blood flow $\left(220 \pm 1 \mathrm{ml} \cdot \mathrm{min}^{-1} \cdot \mathrm{kg}^{-1}\right.$ vs. $209 \pm 16$ $\left.\mathrm{ml} \cdot \mathrm{min}^{-1} \cdot \mathrm{kg}^{-1}\right)$, or the placental clearances of antipyrine (114 $\left.\pm 7 \mathrm{ml} \cdot \mathrm{min}^{-1} \cdot \mathrm{kg}^{-1} v \mathrm{~s} .109 \pm 8 \mathrm{ml} \cdot \mathrm{min}^{-1} \cdot \mathrm{kg}^{-1}\right)$ and urea $(24.5$ $\pm 2.2 \mathrm{ml} \cdot \mathrm{min}^{-1} \cdot \mathrm{kg}^{-1}$ vs. $\left.25.0 \pm 2.1 \mathrm{ml} \cdot \mathrm{min}^{-1} \cdot \mathrm{kg}^{-1}\right)$. Fetal plasma glucose concentration fell significantly $(0.22 \pm 0.01$ $\mathrm{mg} \cdot \mathrm{ml}^{-1}$ to $0.16 \pm 0.01 \mathrm{mg} \cdot \mathrm{ml}^{-1}$ ) during insulin infusion. The insulin effect on fetal glucose uptake occurred over a range of maternal glucose concentrations $\left(0.32 \rightarrow 0.78 \mathrm{mg} \cdot \mathrm{ml}^{-1}\right)$, which were not altered by the infusion of insulin in the fetal compartment.
\end{abstract}

Insulin has a specific effect on increasing fetal glucose uptake and utilization.

\section{Speculation}

The effect of insulin on increasing transplacental fetal glucose uptake is consistent with a growth-promoting role for insulin in the fetus. This action of insulin might be due to a direct effect of insulin on the mechanisms of placental glucose transport, to an alteration of placental glucose catabolism, or simply to the effect of insulin on the transplacental gradient of glucose.

The injection of large doses of insulin into the fetal circulation has previously been shown to cause only minimal decreases in the concentration of fetal plasma glucose in both the rhesus monkey (5) and sheep (7). This observation has been considered as evidence that insulin may not control the rate of fetal glucose utilization. However, even a substantial increase in fetal glucose utilization might not have any dramatic effect on fetal glucose concentration if insulin administration simultaneously led to an increase transfer of glucose from placenta to fetus. Studies on the effect of insulin on the glucose uptake or metabolism of in vitro placenta have produced conflicting results $(2,18,19)$. Thus, observations on the effect of insulin on glucose uptake into the umbilical circulation under stable in vivo conditions are of crucial importance in establishing whether or not insulin controls the rate of fetal glucose utilization. We now report evidence that the infusion of insulin into the fetal circulation leads to an increase in glucose uptake and utilization by the fetus.

\section{MATERIALS AND METHODS}

Ten Western-bred ewes with gestations of 95 to 145 days had polyvinyl catheters placed in the fetal umbilical vein, a fetal pedal artery, a fetal pedal vein, and in the maternal femoral artery while under pentobarbital sedation $(5 \mathrm{mg} / \mathrm{kg})$ and Pontocaine spinal anesthesia (6 mg in hyperbaric glucose). The fetal pedal arterial catheter was advanced just beyond the femoral artery to sample the arterial blood supplying the umbilical artery. The fetal pedal venous catheter was advanced to the femoral vein and was used for the constant antipyrine, urea, and insulin infusions. The animals were allowed to recover from surgery for a minimum of 4 days prior to any study period. Each animal was studied on two occasions within $24 \mathrm{hr}$. The sequence of control and insulin-infusion periods was varied among animals.

During the control period baseline measurements of umbilical blood flow and antipyrine and urea placental clearances were made using the antipyrine and the urea steady state diffusion technique (13). Four simultaneous samples of umbilical venous (v) and arterial (a) blood were obtained at 15- to 20-min intervals and a venoarterial concentration difference for glucose calculated using whole blood glucose concentrations. Applying the Fick principle, glucose uptake and utilization $\left(\dot{Q}_{\mathrm{Glu}}\right)$ by the fetus was calculated as

$$
\dot{\mathrm{Q}}_{\mathrm{Glu}}(\mathrm{mg} / \mathrm{min})=\underset{\text { umbilical whole blood }(\mathrm{v}-\mathrm{a}) \text { glucose }(\mathrm{mg} / \mathrm{ml}) \times}{\text { umbilood flow }(\mathrm{ml} / \mathrm{min})}
$$

A smiliar calculation was made to compute the oxygen consumption of the fetus.

During the insulin study period, the same measurements were repeated while the fetus was receiving a constant intravenous infusion of crystalline bovine zinc insulin (Eli Lilly and Co.). Based on an estimate of fetal weight at the time of surgery, the fetus was given a $\sim 0.1 \mu / \mathrm{kg}$ priming dose followed by a constant infusion at a rate of $\sim 0.24 \mu / \mathrm{kg} / \mathrm{hr}$ over a $2.5-$ 3.5-hr study period. This dose was calculated to approximate a plasma insulin concentration of $1 \mathrm{mU} / \mathrm{ml}$ (7). The sampling period was from 1.5-3.5 hr after beginning the insulin infusion.

Antipyrine was measured on whole blood using a Technicon AutoAnalyzer (13). Urea was measured on plasma using the Beckman BUN analyzer urease method (16). Glucose was measured on whole blood and plasma by a glucose oxidase method $(16,17)$. Statistical analyses were by the paired Student's $t$-test (15).

\section{RESULTS}

Comparison of insulin and control period measurements are shown in Table 1 . Insulin administration had no significant effect on umbilical blood flow $(0.15<P<0.2)$, antipyrine placental clearance $(0.2<P<0.3)$, urea placental clearance $(0.15<P<0.02)$, and fetal oxygen consumption $(0.15<P<$ 0.02 ). Insulin infusion led to a significant fall in fetal arterial plasma glucose concentration $(P<0.001)$, but had no effect on the maternal arterial glucose concentration $(0.2<P<0.3)$.

Mean glucose uptake (utilization) by the fetus increased during insulin infusion $(P<0.001)$, in the face of significant fetal hypoglycemia. Glucose uptake (utilization) increased under the influence of insulin in each study animal. Previous studies have demonstrated a positive correlation of fetal glucose uptake with the maternal arterial glucose concentration (11). Figure 1 confirms the above finding and demonstrates that fetal glucose 
Table 1. Comparison of control to insulin infusion period ${ }^{1}$

\begin{tabular}{|c|c|c|c|c|c|c|c|c|}
\hline & \multirow{2}{*}{$\begin{array}{l}\mathrm{UBF}, \mathrm{ml} \\
\mathrm{min}^{-1} / \mathrm{kg}\end{array}$} & \multirow{2}{*}{$\begin{array}{l}\mathrm{C}_{\text {antl }}, \mathrm{ml} \\
\mathrm{min}^{-1} / \mathrm{kg}\end{array}$} & \multirow{2}{*}{$\begin{array}{c}\mathrm{C}_{\text {urea }}, \mathrm{ml} \mathrm{min}^{-1} / \\
\mathrm{kg}\end{array}$} & \multirow[b]{2}{*}{ (A)Glu, mg/dl } & \multirow[b]{2}{*}{ (a)Glu, mg/dl } & \multicolumn{3}{|c|}{$\dot{\mathrm{Q}}_{\mathrm{Glu}}, \mathrm{mg} \min ^{-1} / \dot{\mathrm{Q}}_{\mathrm{O}}, \mathrm{ml} \mathrm{min}^{-1} /$} \\
\hline & & & & & & $(\mathrm{A}-\mathrm{a}) \mathrm{Glu}, \mathrm{mg} / \mathrm{dl}$ & $\mathrm{kg}$ & $\mathrm{kg}$ \\
\hline Control & $220 \pm 17$ & $114 \pm 7$ & $24.5 \pm 2.2$ & $58.1 \pm 3.7$ & $22.3 \pm 1.1$ & $36.0 \pm 2.7$ & $4.4 \pm 0.7$ & $8.6 \pm 0.7$ \\
\hline Insulin infusion & $209 \pm 16$ & $109 \pm 8$ & $25.0 \pm 2.1$ & $55.9 \pm 5.4$ & $15.9 \pm 1.3$ & $40.5 \pm 4.1$ & $6.9 \pm 0.9$ & $7.7 \pm 0.7$ \\
\hline$n$ & 10 & 10 & 10 & 10 & 10 & 10 & 10 & 8 \\
\hline$P$ & NS & NS & NS & NS & $<0.001$ & $<0.05$ & $<0.001$ & NS \\
\hline
\end{tabular}

${ }^{1}$ A significant increase in fetal glucose uptake during insulin infusion is demonstrated. Results expressed as mean \pm SEM. UBF: umbilical blood flow; $C_{\text {antu: }}$ antipyrine placental clearance; $C_{\text {urea }}$ : urea placental clearance; (A)Glu: maternal arterial plasma glucose concentration; (a)Glu: fetal arterial plasma glucose concentration; (A-a)Glu: maternal-fetal arterial plasma glucose concentration difference; $\dot{Q}_{\text {Glu: }}$ fetal glucose uptake $\dot{Q}_{\mathrm{o}_{2}}$ : fetal oxygen consumption.

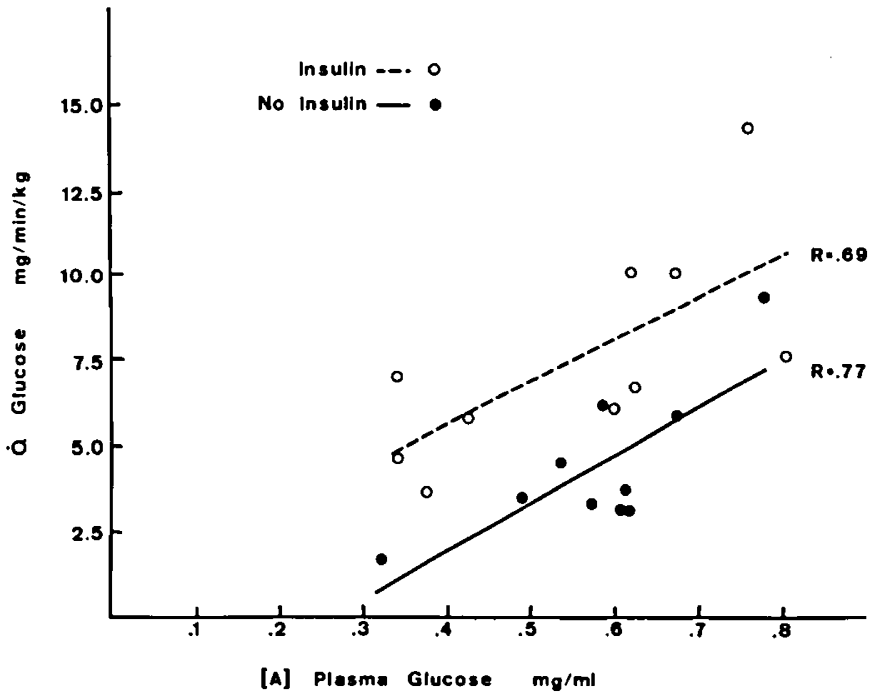

Fig. 1. Fetal glucose uptake via the umbilical circulation (milligrams per min per $\mathrm{kg}$ fetal body weight) vs. maternal arterial $(A)$ plasma glucose concentration. At all values of $[\mathrm{A}]$ the infusion of insulin is associated with significantly $(P<0.001)$ increased fetal glucose uptake.

uptake is a function of both the maternal glucose concentration and the level of insulin in the fetus.

\section{DISCUSSION}

The animals in this report were studied at a wide range of gestational ages (95-145 days). There were no differences in insulin effect detected over this range of age, although the number of animals studied before 100 days is inadequate for making any definitive statement about insulin effects at different stages of fetal maturity.

The dosage of insulin administered to the fetuses in this study would be anticipated to cause an increase in fetal plasma insulin concentration 20-50 times the usual physiologic concentrations. This large dose was selected because previous studies using similar doses were interpreted as showing little effect of insulin in controlling fetal glucose utilization. It cannot be stated whether more modest insulin doses, and thus more physiologic insulin concentrations, would lead to similar findings.

The mechanism by which insulin infusion leads to increased glucose umbilical uptake needs further investigation. A significant increase in the maternal to fetal plasma glucose concentration difference occurred in the present study (Table 1) and was secondary to a fall in the fetal arterial glucose concentration. Previous studies have demonstrated the relationship between fetal glucose uptake and the maternal to fetal glucose concentration difference (11). Thus, insulin might increase fetal glucose uptake simply by decreasing the fetal arterial glucose concentration and enlarging the glucose cocentration gradient across the placenta. However, as shown in Table 1 , the increase in fetal glucose uptake demonstrated in the present study $(+57 \%)$ exceeds the magnitude of the increase in the maternal to fetal glucose concentration difference $(+12 \%)$.

Insulin may have a direct effect on placental glucose metabolism or transport (19). Any decrease in placental glucose utilization, even if there were a constant glucose uptake by the placenta from the maternal circulation, would lead to increased glucose availability to the fetus. Insulin might have such an effect, although this would be inconsistent with current concepts of insulin action on tissues.

A direct effect of insulin on placental glucose transport is also possible since insulin is known to stimulate glucose transport across cell membranes in several tissues. Recent studies demonstrating insulin receptors on the plasma membranes of human placenta are consistent with this possibility $(10,12)$.

The effect of insulin on increasing fetal glucose utilization contradicts previous evidence suggesting little effect of insulin on fetal tissues $(1,4,6)$ but is consistent with other in vitro (3) and in vivo $(7,14)$ evidence.

\section{CONCLUSION}

Because of the anabolic nature of its actions, insulin might have a growth-promoting function in the fetus. The macrosomia seen in human fetal hyperinsulinemic states (infants of diabetic mothers) (9) and the growth failure noted in infants with agenesis of the pancreas (8) would support such a role. It is possible that the growth-promoting effect of insulin is mediated in part by its effect on increasing fetal glucose uptake and utilization demonstrated in this study.

\section{REFERENCES AND NOTES}

1. Alexander, D. P., Britton, H. H., Cohen, N. M., and Nixon, D. A.: The response of the sheep foetus and the young lamb to anti-insulin serum. Biol. Neonate, 15: 142 (1970).

2. Battaglia, F. C., Meschia, G., Blechner, J., and Barron, D. H.: Effect of insulin and poisons on glucose uptake of sheep and goat placenta. Amer. J. Physiol., 200: 64 (1961).

3. Bocek, R. M., and Beatty, C. H.: Effect of insulin on the carbohydrate metabolism of fetal rhesus monkey muscle. Endocrinology, 85: 615 (1969).

4. Britton, H. G., and Blade, M.: The incorporation of radioglucose into glycogen in foetal and neonatal rat diaphragm in vitro: The effect of insulin. Biol. Neonate, 16: 370 (1970).

5. Chez, R. A., Mintz, D. H., Horger, E. O., III, and Hutchinson, D. L. Factors affecting the response to insulin in the normal subhuman pregnant primate. J. Clin. Invest., 49: 1517 (1970).

6. Clark, C. M., Cahill, G. F., and Soeldner, J. S.: Effects of exogenous insulin on the rate of fatty acid synthesis and glucose C-14 utilization in the twenty-day rat fetus. Diabetes, 17: 362 (1968).

7. Colwill, J. R., Davis, J. R., Meschia, G., Makowski, E. L., Beck, P., and Battaglia, F. C.: Insulin-induced hypoglycemia in the ovine fetus in utero. Endocrinology, 87: 710 (1970).

8. Dourov, N., and Buyl-Strouvens, M. L.: Agenesie due pancreas: Observation anatomo-clinique d'un cas de diabete sucre, avec steatorrhu at hypotrophie, chez un nouveau-ne. Arch. Franç. Pediat., 26: 64 (1969).

9. Farquhar, J. W.: The child of the diabetic woman. Arch. Dis. Childhood, 34: 76 (1959).

10. Haour, F., and Betrand, J.: Insulin receptors in the plasma membranes of human placenta. J. Clin. Endocrinol., Metab., 38: 334 (1974).

11. James, E. J., Raye, J. R., Gresham, E. L., Makowski, E. L., Meschia, G. and Battaglia, F. C.: Fetal oxygen consumption, carbon dioxide production, and glucose uptake in a chronic sheep preparation. Pediatrics, 50: 361 (1972).

12. Marshall, R. N., Underwood, L. E., Voina, S. J., Foushee, D. B., and Van 
Wyk, J. J.: Characterization of the insulin and somatomedin-C receptors in human placental cell membranes. J. Clin. Endocrinol. Metab., 39: 283 (1974).

13. Meschia, G., Battaglia, F. C., and Bruns, P. D.: Theoretical and experimental study of transplacental diffusion. J. Appl. Physiol., 22: 1171 (1967).

14. Rabain, F., and Pison, L.: Effect of insulin on the materno-fetal transfer of glucose in the rat. Hormone Metab. Res., 6: 376 (1974).

15. Remington, R. D., and Schork, M. A.: Statistics with Application to the Biological and Health Sciences, p. 213 (Prentice Hall, Englewood, NJ, 1970).

16. Simmons, M. A., Meschia, G., Makowski, E. L., and Battaglia, F. C.: Fetal metabolic response to maternal starvation. Pediat. Res., 8: 830 (1974).

17. Sols, A., and de la Fuente, G.: Hexokinase and other enzymes of sugar metabolism in the intestine. In: J. H. Quastel: Methods in Medical Research, Vol. 9, pp. 302-309 (Year Book Publishers, Chicago, 1961).

0031-3998/78/1202-0090\$02.00/0

Copyright (1) 1978 International Pediatric Research Foundation, Inc.
18. Szabo, A. J., and Grimaldi, R. D.: The effect of insulin on glucose metabolism of the incubated human placenta. Amer. J. Obstet. Gynecol., 106: 75 (1970).

19. Villee, C. A.: The metabolism of human placenta in vitro. J. Biol. Chem. 205: 113 (1953).

20. Michael A. Simmons, M.D., is an Established Investigator of the American Heart Association.

21. This research was supported by NIH Grants HD-00781, HD-01866 and a Basil O'Connor Starter Research Grant from the National Foundation March of Dimes.

22. Requests for reprints should be addressed to: M. A. Simmons, M.D., University of Colorado, Medical Center, 4200 East Ninth Ave., Denver, CO 80220 (USA).

23. Received for publication February 22, 1977

24. Accepted for publication May 6, 1977

Pediat. Res. 12: 92-94 (1978)

Light patent ductus arteriosus

oxygen photochemistry

\title{
Patent Ductus Arteriosus: A New Light on an Old Problem
}

\author{
RONALD I. CLYMAN ${ }^{(23)}$ AND ABRAHAM M. RUDOLPH \\ Cardiovascular Research Institute and the Departments of Pediatrics and Obstetrics, Gynecology and Reproductive \\ Sciences, University of California, San Francisco, California, USA
}

\section{Summary}

It has been suggested previously that delayed closure of the ductus arteriosus in premature infants is related to an ineffective constriction in response to an increase in arterial $\mathbf{P O}_{2}$. The contractile effects of increased $\mathrm{PO}_{2}$ and excess $\mathrm{K}^{+}$were studied in rings of ductus arteriosus from early $(70 \pm 4$ days, $n=9)$ and late $(137 \pm 3$ days, $n=11)$ gestation fetal lambs. Studies were performed in a laboratory using overhead fluorescent lighting or in a dark, enclosed box. Room light relaxed the oxygen-induced contraction in immature vessels but had no significant effect on the $\mathrm{K}^{+}$-induced contraction. Room light did not alter either the oxygen or $\mathrm{K}^{+}$-induced contractile responses in mature vessels. When comparing oxygen induced contractions in room light in immature vessels $(0.27 \pm 0.13 \mathrm{~g}, n=9)$ vs. mature vessels $(0.82 \pm 0.06 \mathrm{~g}, n=11)$ there appeared to be an increased response to oxygen with advancing gestational age. However, when the oxygen-induced responses of immature $(0.59 \pm 0.15 \mathrm{~g}, n=9)$ and mature $(0.82 \pm 0.06 \mathrm{~g}, n=11)$ vessels were performed in an environment excluding room light, no significant gestational difference was observed. The role of oxygen in delayed closure of the ductus arteriosus of premature infants will need further evaluation.

\section{Speculation}

The difference in sensitivity to photorelaxation between rings of ductus arteriosus from immature and mature lambs may be associated with biochemical differences in vessels between early and late gestation.

In contrast to full-term infants in whom functional closure of the ductus arteriosus occurs within the first $24 \mathrm{hr}$ after birth, preterm infants frequently have delayed spontaneous closure
(3). The exact mechanism responsible for the constriction of the ductus arteriosus at birth and for its delay in closure in preterm infants is as yet unknown. Numerous observations have drawn attention to the importance of the postnatal increase in arterial oxygen pressure $\left(\mathrm{PO}_{2}\right)$ for muscular closure of the ductus arteriosus $(6,11,13,14)$. Rudolph (18) has suggested that the higher incidence of patent ductus arteriosus in preterm infants might be due to immaturity of ductal smooth muscle. Several in vitro studies have suggested that delayed closure of the ductus arteriosus in preterm infants is related to an ineffective constriction in response to increases of $\mathrm{PO}_{2}(10,14,15)$. This development of responsiveness to $\mathrm{O}_{2}$ has been attributed to maturation of either specific receptors for oxygen (15) or vascular smooth muscle contractility $(10)$. The results reported below identify a third possible explanation for this in vitro developmental response of the ductus arteriosus to oxygen. Several years ago Furchgott et al. (9) observed a photoactivated relaxation of smooth muscle in isolated strips of rabbit aorta. This relaxation was reversible, depended on the pre-exposure level of active contraction, and occurred in the presence or absence of oxygen. We have observed that vessels from immature lambs are very sensitive to photorelaxation by overhead fluorescent lights, used for general illumination in the laboratory, whereas those from older lambs are insensitive. We suggest that the lack of responsiveness to oxygen of immature vessels in vitro may be secondary to the effects of overhead laboratory lights on immature vessels and that there may be minimal gestational differences in contractile response to oxygen.

\section{MATERIALS AND METHODS}

Time-dated fetal lambs, between 56 and 145 days of gestational age (term is 150 days), were delivered by cesarean 